\title{
Orthodontic protraction of the third molars to the posterior teeth missing area
}

\author{
Kang-gyu Lee', Je-Hyeok Park', Jin Jeon', Jae-yoen Kang', Jong Ghee Kim,2, Young-Mi Jeon ${ }^{1,2 *}$ \\ 'Department of Orthodontics, School of Dentistry, Institute of Oral Biosciences, Jeonbuk National University, Jeonju, Republic of Korea \\ ${ }^{2}$ Biomedical Research Institute of Jeonbuk National University Hospital, Jeonju, Republic of Korea
}

The prolonged neglect of the posterior teeth missing area may cause mesial drift, extrusion, unexpected movement of the adjacent teeth and alveolar bone loss with occlusion collapse. Therefore it is recommended to treat that area by the prosthesis as soon as possible after tooth missing. However, if orthodontic treatment is applied to move the remained teeth, it can create improved biomechanical dentoalveolar environment. The use of the third molars in teeth missing area provides advantages as optimizing of prosthesis size. However, crown shape, location, soundness of the third molar and possible of eruption failure should be considered. In this case report, two patients closed a second teeth missing site and reduced the size of the first and second teeth missing area for an implant by protraction of impacted third molars. This case reports the considerations for closing or reducing the posterior teeth space with protracting the third molars by comparing two patients. (J Dent Rehabil Appl Sci 2019;35(4):260-9)

Key words: posterior teeth missing; posterior teeth loss; third molar protraction

\section{서론}

장기간 방치된 구치 결손부위는 대합치의 정출, 인접치 의 tipping, 치조골의 소실 등을 야기할 수 있으며 이러한 문제를 예방하기 위해 통상적으로 결손부위에 직접 보 철 수복 치료가 이루어지고 있다. 보철 수복 치료는 짧은 시간 안에 결손부위를 회복할 수 있다는 장점을 가지지 만 치아 결손 공간을 교정적으로 재정비하여 잔존 치아 를 적절한 위치로 이동시키면 최적의 크기와 형태로 보철 수복이 가능하고, 기능교합 시 힘의 분산을 고르게 할 수 있다. ${ }^{1,2}$ 더불어 교정적 치아 이동을 통한 결손부위의 공 간폐쇄 시 추가적인 보철 수복 없이 건전한 자연치아로 결손부위를 회복할 수 있어 치주 생리적으로 보다 이점 을 가질 수 있다. ${ }^{3}$ 특히 자가치아를 이용한 공간 폐쇄의

*Correspondence to: Young-Mi Jeon

Professor, Department of Orthodontics, School of Dentistry, Institute of Oral Bioscience, Jeonbuk National University; Biomedical Research Institute of Jeonbuk National University Hospital, 20, Geonji-ro, Deokjin-gu, Jeonju-si, Jeollabuk-do, 54907, Republic of Korea

Tel: +82-63-250-2130, Fax: +82-63-250-2139, E-mail: young@jbnu.ac.kr Received: October 11, 2019/Last Revision: October 25, 2019/Accepted: November 11,2019
이점을 생각해 볼 때, 대구치 결손부위에 제 3 대구치의 활 용을 적극적으로 고려해 볼 수 있다. ${ }^{4}$ 상악에 비해 하악 의 제3대구치 맹출 경로가 정상교합을 이루기에 불리함 에도 불구하고 Gooris 등, ${ }^{5}$ Orton-Gibbs 등, ${ }^{6,7}$ De-la-Rosa-Gay 등 8 의 연구에 의하면 제 2 대구치 발치 시 제 3 대구 치의 $80 \%$ 이상에서 적절한 교합을 형성할 수 있도록 자 연 맹출한다고 보고했다. Richardson과 Richardson ${ }^{10}$ 은 이를 정리하여 정상적인 크기의 제 3 대구치는 초기 매복 되어 있던 치축, 발육상태와 상관 없이 대부분의 경우 제 2대구치를 대체할 수 있는 적절한 교합을 형성할 수 있다 고 했다. 이는 구치부가 상실되어 공간이 확보된 경우 제 3 대구치의 적절한 맹출을 유도하여 결손부위 교합을 회 복할 수 있음을 시사한다. 하지만 후방구치를 교정적으 로 전방이동 시, 치아 이동에 따른 전체 치료기간의 연장

CopyrightC 2019 The Korean Academy of Stomatognathic Function and Occlusion. (c) It is identical to Creative Commons Non-Commercial License. 
과 전방으로의 힘에 따른 mesial-in rotation, mesial tipping 등의 문제를 수반하게 된다. 특히 결손부위로의 치 아 이동은 mesial tipping되는 경향이 강해 이에 대한 예 방을 위해 구치부 uprighting spring, intrusion arch, tip back을 부여한 loop 등의 장치가 사용되고 있다. 다른 방 법으로 mesial tipping 및 mesial-in rotation을 조절하며 구치부의 공간폐쇄를 하기 위해 root spring, extension arm을 사용한 구치부 protraction, cantilever intrusion arch, buccopalatal wire에 부여한 open coil spring, sling shot appliance 등을 사용할 수 있고 이를 통해 효과적인 구치부 up-righting을 시행할 수 있다.

\section{증례보고}

\section{증례 1}

임플란트 식립 전 대합치 정출 해소를 위해 19세 여 성환자가 내원했다. 구외사진과 구내 소견상 다수의 구 치부 root rest와 이로 인한 대합치의 정출, 인접치의 mesial-in rotation 양상을 확인할 수 있었다(Fig. 1). 파노 라마 상에서 \#26 치아의 우식을 추가적으로 확인할 수 있었고(Fig. 2), cephalometric 분석에서 골격적 II급 관계 와 큰 IMPA (the angle of the lowermost tangent to the

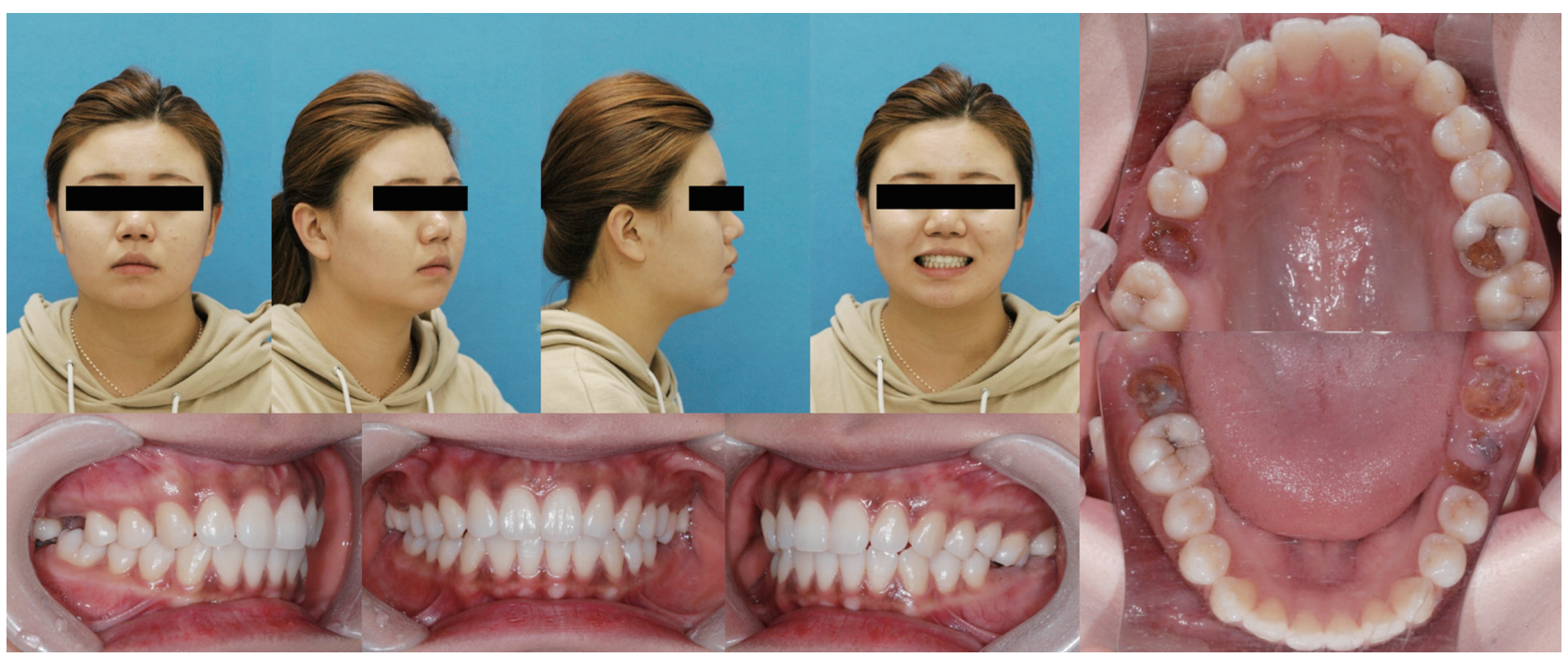

Fig. 1. Pre-treatment clinical photographs of Case I. She has hopeless posterior teeth with deep caries and root rest but well aligned anterior teeth.

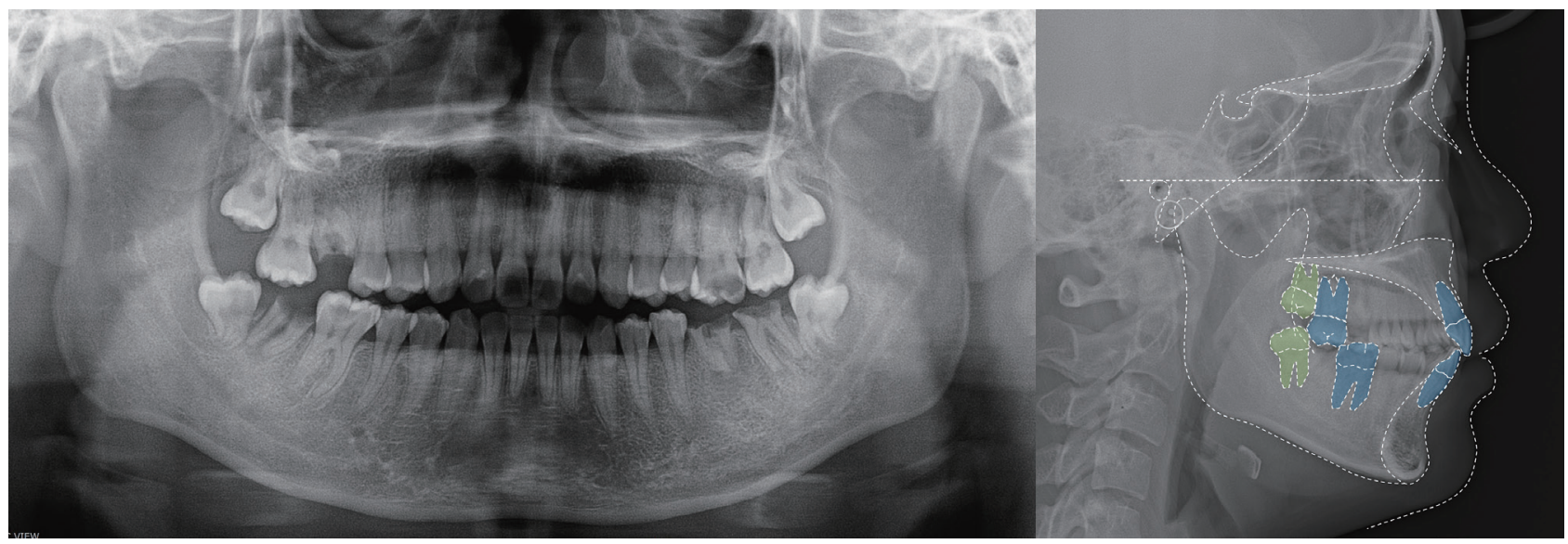

Fig. 2. Pre-treatment panoramic and lateral cephalometric radiographs of Case I. Maxillary second molar and mandibular first molar was traced because treatment plan included maxillary second molar protraction. 
mandible and the long axis of mandibular incisors), 정 상 범위의 상악 전치부 치축을 확인할 수 있었다(Table 1). 이 환자를 골격적 II급 관계를 가지고 있는 skeletodentoalveolar dysplasia로 진단하고 다수 구치부 치아의

Table 1. Case I patient's pre-treatment cephalometric analysis. It shows skeletal Class II relationship with both jaw protrusion and labio-version of mandibular incisor

\begin{tabular}{lcc}
\hline Measurement & Mean & Initial \\
\hline SNA $\left(^{\circ}\right)$ & 81.6 & $90.9^{* *}$ \\
SNB $\left(^{\circ}\right)$ & 79.2 & $85.5^{* *}$ \\
ANB $\left(^{\circ}\right)$ & 2.5 & $5.4^{*}$ \\
FMA $\left(^{\circ}\right)$ & 24.3 & $19.2^{*}$ \\
FMIA $\left(^{\circ}\right)$ & 59.8 & 56.4 \\
IMPA $\left(^{\circ}\right)$ & 95.9 & $104.4^{*}$ \\
L1 to APo $(\mathrm{mm})$ & 4.7 & $7.0^{*}$ \\
U1 to FH $\left(^{\circ}\right)$ & 116.0 & 113.4 \\
U1 to SN $\left(^{\circ}\right)$ & 106.9 & 108.9 \\
IIA $\left(^{\circ}\right)$ & 123.8 & 123.0 \\
\hline
\end{tabular}

*, 1 standard deviation; **, 2 standard deviation.

$\mathrm{SNA}$, the angle of sella-nasion-A point; $\mathrm{SNB}$, the angle of sellanasion-B point; $A N B$, the angle of A point-nasion-B point; FMA, Frankfort mandibular plane angle; FMIA, Frankfort mandibular incisor angle; IMPA, the angle of the lowermost tangent to the mandible and the long axis of mandibular incisors; L1 to APo, linear distance from tip of lower incisor to A point to pogonion line; $\mathrm{U} 1$ to $\mathrm{FH}$, the angle of the long axis of maxillary central incisors between Frankfort plane; $\mathrm{U} 1$ to $\mathrm{SN}$, the angle of the long axis of maxillary central incisors between sella-nasion plane; IIA, interincisal angle. root rest, 대합치의 extrusion 및 하악 정중선의 좌측 편 위를 문제 목록으로 파악하여 치료 계획을 세웠다.

Root rest와 우식에 이환된 치아를 발치하고 정출되어 있는 치아의 intrusion 후 단일 구치가 결손된 부위는 후 방구치를 통한 치아 결손부위 공간폐쇄를 계획했으며 제 1,2 대구치가 모두 결손된 하악 좌측 부위는 제 3 대구치 전방견인으로 치아 상실부위 공간 크기를 줄인 후 임플 란트를 식립하기로 했다.

Leveling 후 정출되어 있던 상악 제 2 대구치의 intrusion 을 시행하고 근심 이동해야 하는 제 2 대구치의 치체 이 동을 도모하기 위해 tip back을 부여한 L-loop을 사용해 공간폐쇄를 진행했고 이 때, 매복되어 있는 제 3 대구치의 효과적인 근심이동을 위해 골성 고정원을 사용했다. 하 악 좌측 부위에 임플란트 식립을 위한 공간을 남기고, 후 방 치아의 mesial tipping을 방지하며 근심이동을 시행 하여 교정치료를 마무리했다. 환자는 2 년의 비교적 짧은 기간의 교정치료를 통해 조화로운 구치부 교합관계와 임플란트 식립을 위한 적절한 공간을 남겨놓을 수 있었 고 최종 수복을 완료했다. 치료 전후의 cast 모델 중첩과 cephalometric 중첩에서 치아 결손부위로 후방 구치들의 전방이동이 이루어졌음을 확인할 수 있었다. 치료 전후 IMPA (the angle of the lowermost tangent to the mandible and the long axis of mandibular incisors) 값의 감 소 외에 큰 변화를 보이지는 않았다(Fig. 3, 4, 5, Table 2).

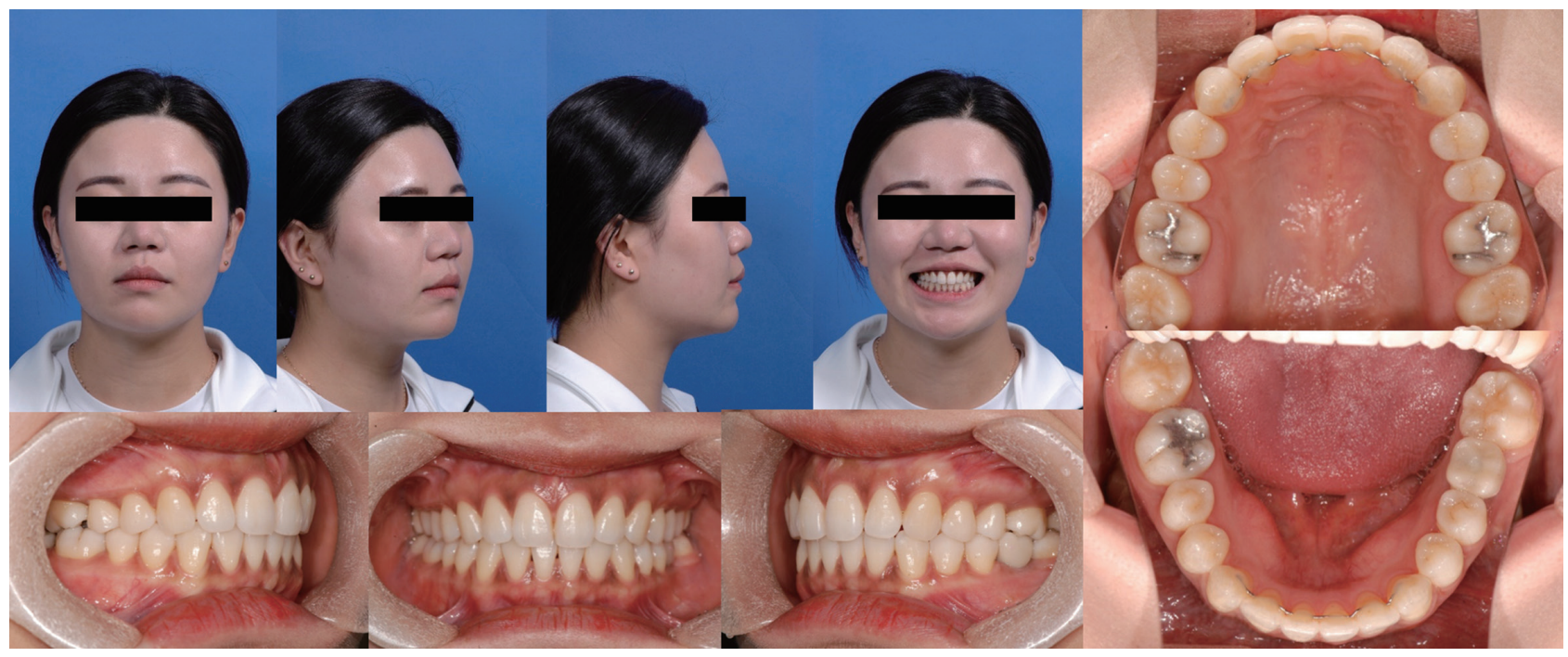

Fig. 3. Post-treatment clinical photographs of Case I. The maxillary first molars were replaced by second molars. The mandibular second molars were replaced by third molars and mandibular left first molar was replaced by a prosthetic implant. 


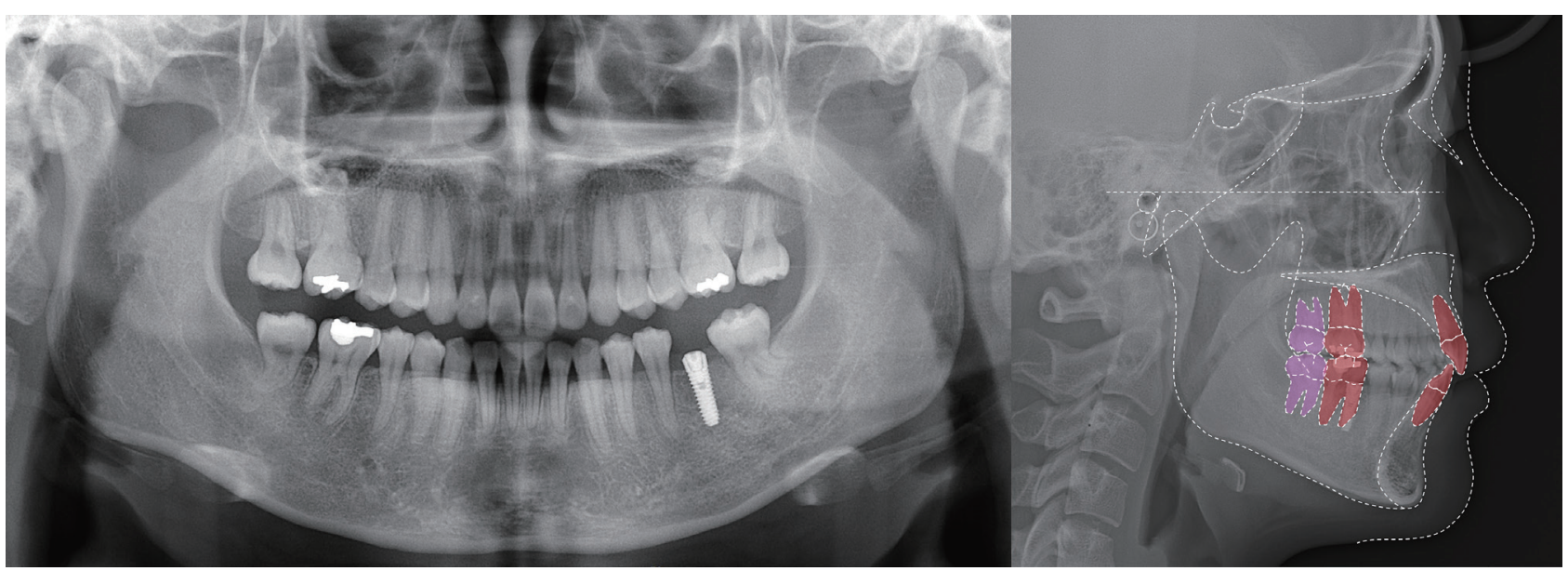

Fig. 4. Post-treatment panoramic and lateral cephalometric radiographs of Case I.

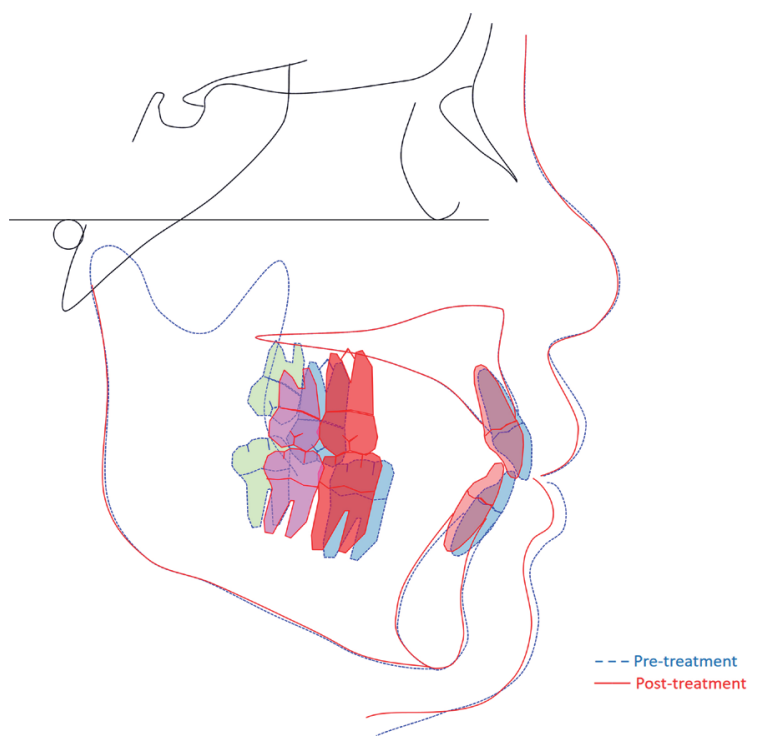

Fig. 5. Superimposition of pre- and post-treatment lateral cephalograms of Case I. Blue line means pretreatment tracing and red line means post-treatment tracing. Blue and red teeth indicate maxillary second molars and mandibular first molar's position before and after treatment. Green and pink teeth means maxillary and mandibular third molar's position before and after orthodontic treatment.

\section{증례 2}

두 번째 환자는 24세 남성으로 위 덧니를 배열하고 싶 다는 주소로 내원했다. 구외소견과 구내 소견상 다수 의 구치부 치아 결손과 대합치의 정출, 결손부위로의 tipping 양상을 확인할 수 있었다(Fig. 6). 파노라마 상 에서 예후가 불량 치아를 추가로 확인할 수 있었고(Fig.
Table 2. Case I patient's pre- and post-treatment cephalometric analysis. It shows dental change of both incisors but skeletal pattern was not changed significantly

\begin{tabular}{lrcc}
\hline Measurement & Mean & Initial & Final \\
\hline SNA $\left(^{\circ}\right)$ & 81.6 & $90.9^{* *}$ & $89.9^{* *}$ \\
SNB $\left(^{\circ}\right)$ & 79.2 & $85.5^{* *}$ & $85.1^{* *}$ \\
ANB $\left(^{\circ}\right)$ & 2.5 & $5.4^{*}$ & $4.8^{*}$ \\
FMA $\left(^{\circ}\right)$ & 24.3 & $19.2^{*}$ & $19.2^{*}$ \\
FMIA $\left(^{\circ}\right)$ & 59.8 & 56.4 & 59.6 \\
IMPA $\left(^{\circ}\right)$ & 95.9 & $104.4^{*}$ & 101.2 \\
L1 to APo $(m m)$ & 4.7 & $7.0^{*}$ & 5.9 \\
U1 to FH $\left(^{\circ}\right)$ & 116.0 & 113.4 & $108.8^{*}$ \\
U1 to SN $\left(^{\circ}\right)$ & 106.9 & 108.9 & 103.6 \\
IIA $\left(^{\circ}\right)$ & 123.8 & 123.0 & 130.8 \\
\hline
\end{tabular}

*, 1 standard deviation; **, 2 standard deviation.

SNA, the angle of sella-nasion-A point; SNB, the angle of sellanasion-B point; $A N B$, the angle of $A$ point-nasion-B point; FMA, Frankfort mandibular plane angle; FMIA, Frankfort mandibular incisor angle; IMPA, the angle of the lowermost tangent to the mandible and the long axis of mandibular incisors; L1 to APo, linear distance from tip of lower incisor to A point to pogonion line; $\mathrm{U} 1$ to $\mathrm{FH}$, the angle of the long axis of maxillary central incisors between Frankfort plane; $\mathrm{U} 1$ to $\mathrm{SN}$, the angle of the long axis of maxillary central incisors between sella-nasion plane; IIA, interincisal angle.

7), cephalometric 분석에서 골격적 I급 관계와 큰 FMA (Frankfort mandibular plane angle), 작은 IIA (interincisor angle)을 보였다(Table 3). Hyperdivergent 양상의 골 격적 I급 관계를 가지고 있는 skeletodentoalveolar dysplasia로 진단하고 상하악의 crowding, 절단연 교합, 다 수의 구치부 결손을 문제 목록으로 파악하여 치료 계획 을 세웠다. 


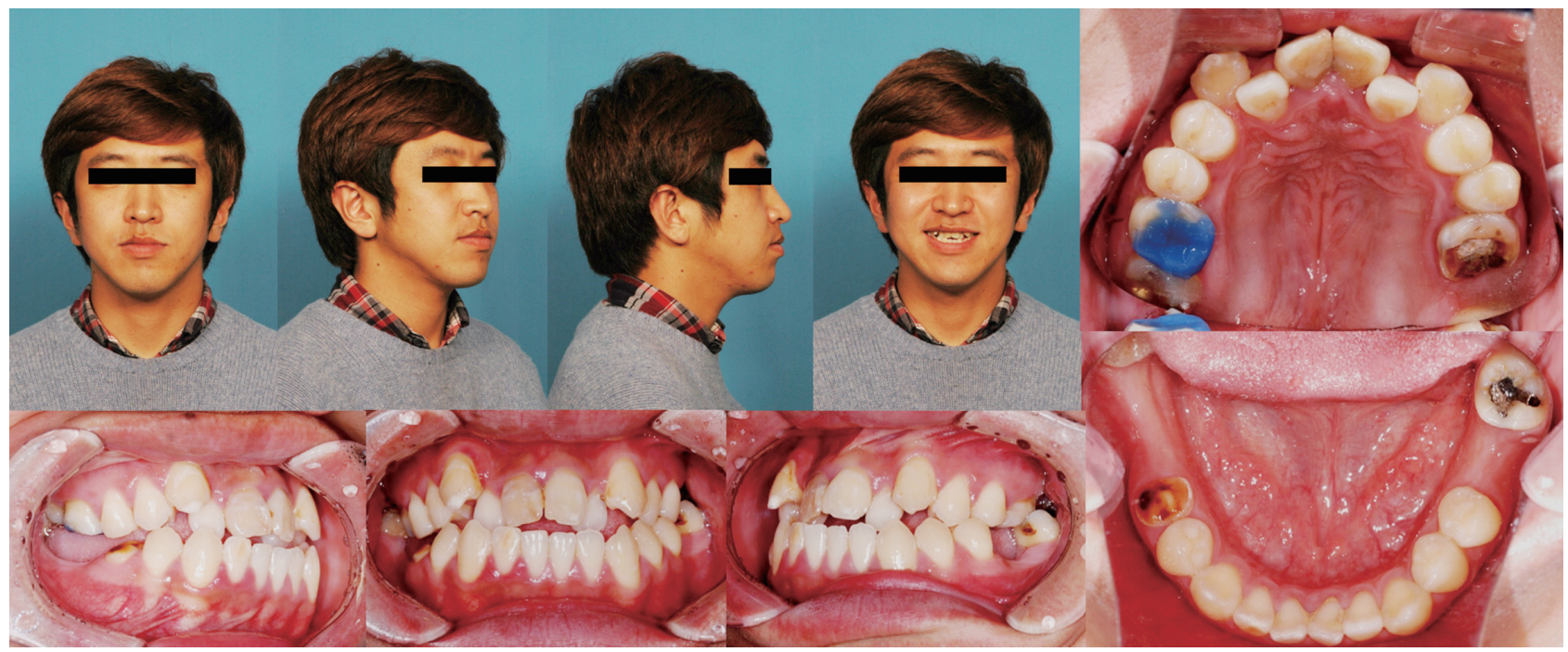

Fig. 6. Pre-treatment clinical photographs of Case II. He has teeth missing and hopeless teeth with deep caries and root rest on posterior area but also anterior crowding.

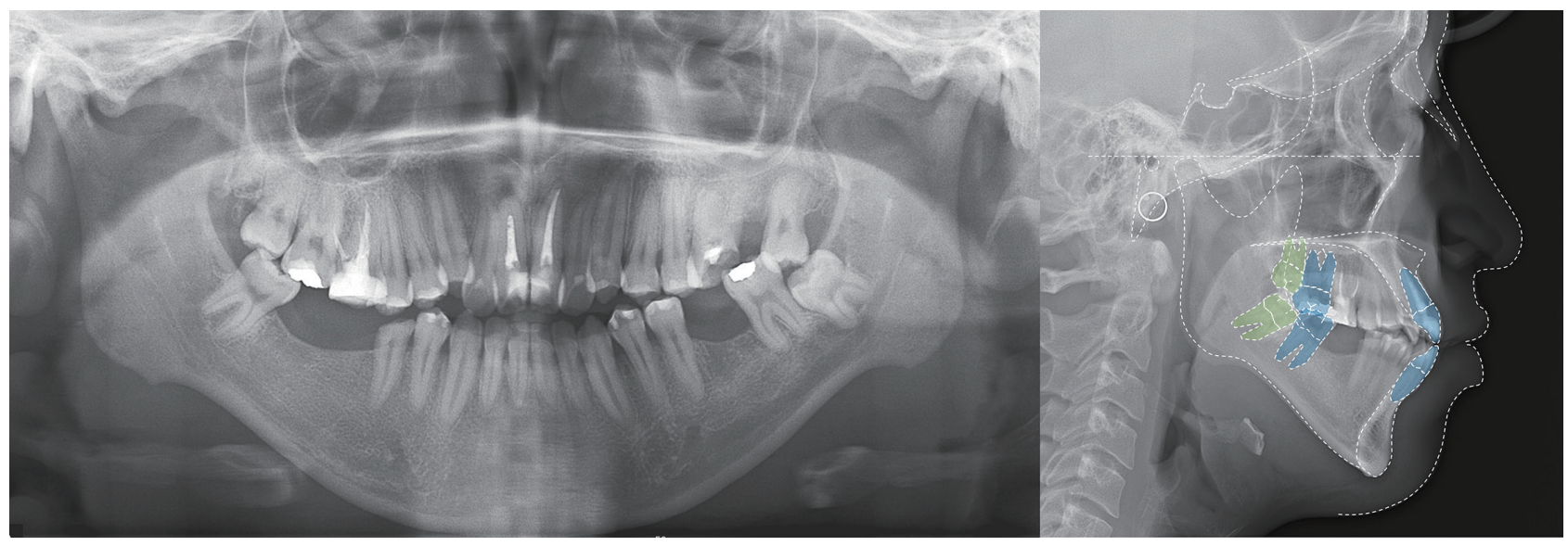

Fig. 7. Pre-treatment panoramic and lateral cephalometric radiographs of Case II. Maxillary and mandibular second molar was traced because the upper and lower first molars were defective or missing and treatment plan included second molar protraction.

Table 3. Case II patient's pre-treatment cephalometric analysis. It shows skeletal Class I relationship with hyperdivergent pattern

\begin{tabular}{lcc}
\hline Measurement & Mean & Initial \\
\hline SNA $\left(^{\circ}\right)$ & 82.5 & $78.6^{*}$ \\
SNB $\left(^{\circ}\right)$ & 80.4 & $74.9^{*}$ \\
ANB $\left(^{\circ}\right)$ & 2.1 & 3.7 \\
FMA $\left(^{\circ}\right)$ & 22.7 & $34.0^{* *}$ \\
FMIA $\left(^{\circ}\right)$ & 60.7 & 55.6 \\
IMPA $\left(^{\circ}\right)$ & 96.6 & 90.4 \\
L1 to APo $(m m)$ & 4.6 & $9.5^{* *}$ \\
$\mathrm{U} 1$ to FH $\left(^{\circ}\right)$ & 116.3 & 120.0 \\
$\mathrm{U} 1$ to SN $\left(^{\circ}\right)$ & 108.7 & 106.2 \\
IIA $\left(^{\circ}\right)$ & 124.4 & $115.7^{*}$ \\
\hline
\end{tabular}

*, 1 standard deviation; **, 2 standard deviation.

$\mathrm{SNA}$, the angle of sella-nasion-A point; $\mathrm{SNB}$, the angle of sellanasion-B point; ANB, the angle of A point-nasion-B point; FMA, Frankfort mandibular plane angle; FMIA, Frankfort mandibular incisor angle; IMPA, the angle of the lowermost tangent to the mandible and the long axis of mandibular incisors; L1 to APo, linear distance from tip of lower incisor to A point to pogonion line; U1 to FH, the angle of the long axis of maxillary central incisors between Frankfort plane; U1 to SN, the angle of the long axis of maxillary central incisors between sella-nasion plane; IIA, interincisal angle. 
Root rest와 예후가 불량한 치아를 발치하고 전방부 crowding을 해소 후 단일 구치가 결손된 부위는 후방 구 치의 근심이동을 통해 치아결손 부위 공간을 폐쇄 하기 로 계획했다. 제 1,2 대구치가 결손된 상악 좌측, 하악 우 측부위는 제 3 대구치 전방견인으로 치아 상실부위 공간 을 줄인 후 임플란트를 식립하기로 했다.

Leveling 후 근심경사되어 있는 구치를 up-righting 시 키기 위해 one piece intrusion arch를 사용하고 tip back 을 부여한 L-loop과 구치 근심이동을 위한 골성 고정원 을 사용했다. 매복되어 있던 하악 좌측 제 3 대구치의 자
연 맹출 후 leveling을 위해 sectional L-loop을 사용했고, hyperdivergent한 안모 개선을 위해 상악 구치부 intrusion을 시행했다. 환자는 5년 2개월의 교정치료 후 양호 한 구치부 교합관계와 임플란트 식립 공간을 얻을 수 있 었고 임플란트 최종 수복을 완료했다. 치료 전후의 cast 모델 중첩과 cephalometric 중첩에서 치아 결손 부위로 후방 구치들의 전방이동이 이루어졌음을 확인할 수 있었 다. 치료 전후 IMPA의 감소, 이에 따른 IIA의 증가 외에 골격적으로 큰 변화는 보이지 않았다(Fig. 8, 9, 10, Table 4).

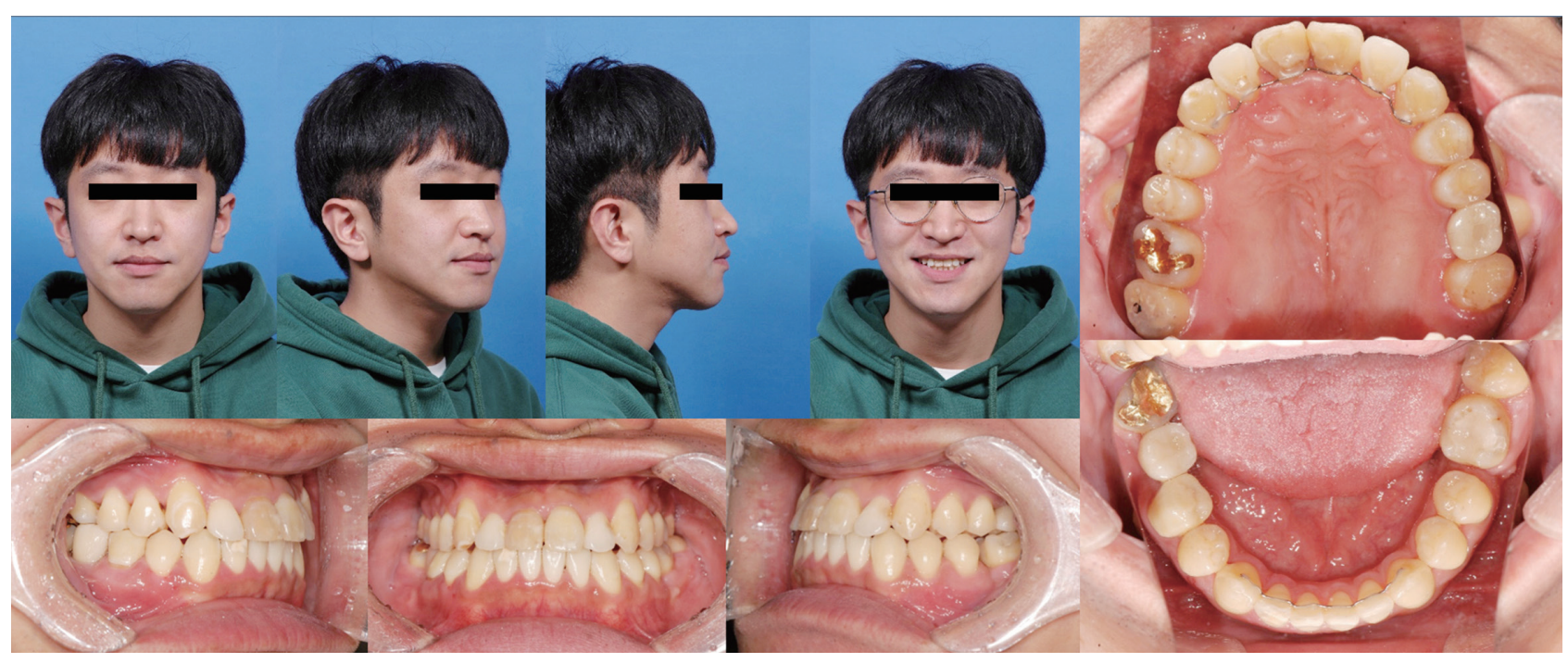

Fig. 8. Post-treatment clinical photographs of Case II. The right maxillary and left mandibular first molars were replaced by second molars and left maxillary and right mandibular first molars were replaced by prosthetic implants.

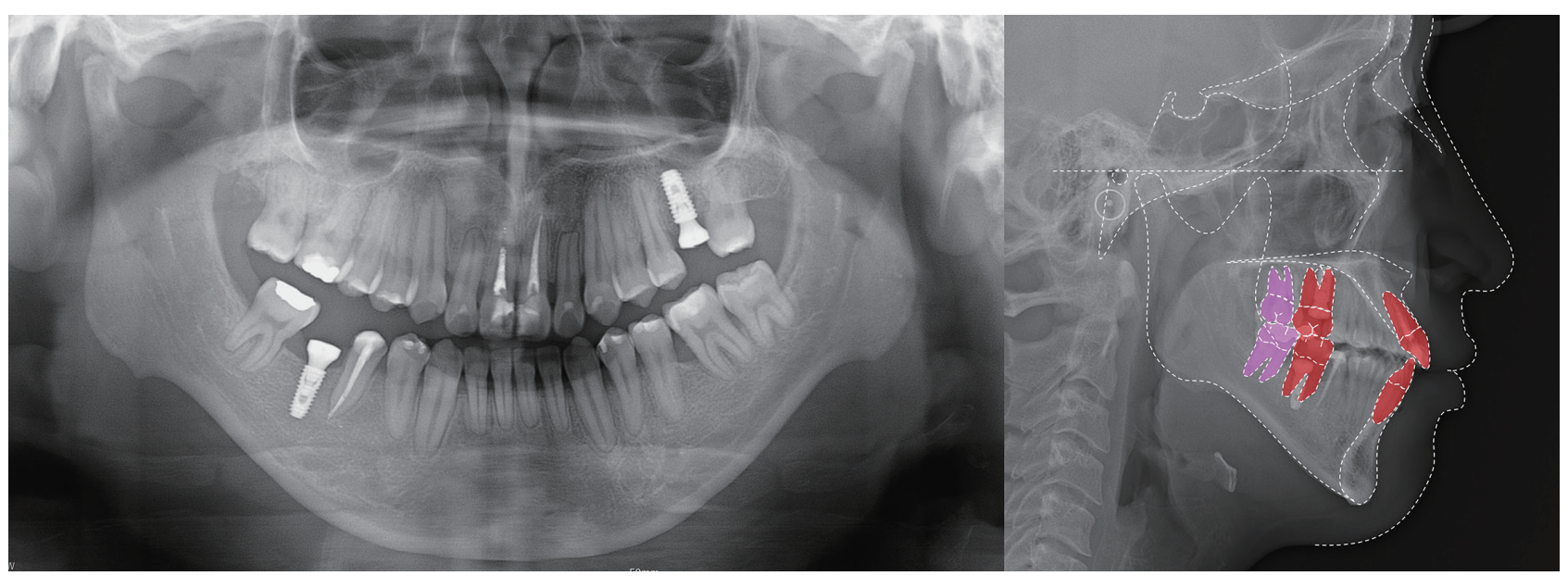

Fig. 9. Post-treatment panoramic and lateral cephalometric radiographs of Case II. 


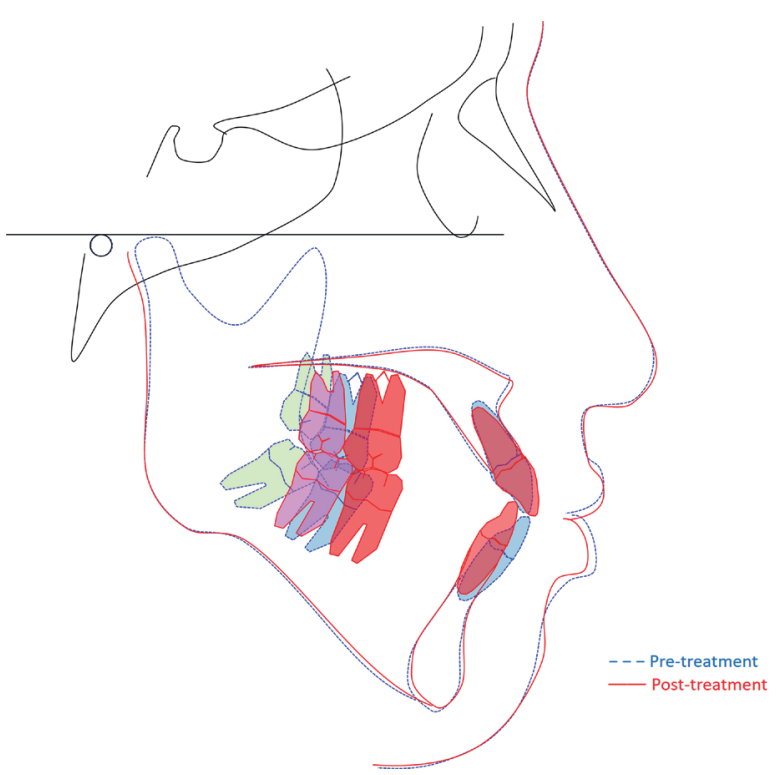

Fig. 10. Superimposition of pre- and post-treatment lateral cephalograms of Case II. Blue line means pretreatment tracing and red line means post-treatment tracing. Blue and red teeth indicate maxillary and mandibular second molar's position before and after treatment. Green and pink teeth means maxillary and mandibular third molar's position before and after orthodontic treatment.

\section{고찰}

두 환자는 제 1 대구치 결손부위를 교정적으로 이동시 킨 후방구치로 대체하고, 제 1,2 대구치가 모두 결손된 부 위는 제 3 대구치를 전방이동하여 임플란트 식립을 최소 화했다는 점에서 치료 방법의 공통점을 가지고 있다. 하 지만 두 번째 환자는 전체 치료 기간이 2 배 이상의 더 길 었으며, 그럼에도 불구하고 치료 종료 후 retention 기간 중 하악 좌측 대구치의 space relapse 경향을 보였다. 이 렇게 무치악 부위로 치아를 이동시키려 할 때 전체 치료 기간 및 치료 후 안정성의 차이가 발생한 원인으로 환자 의 나이, 치조골 상태, 치근 흡수 등을 고려해 볼 수 있다. Stepovich ${ }^{8}$ 는 하악에서 무치악 부위를 폐쇄하는 실험에 서 치료 시작 시 상대적으로 연령이 높은 환자가 치료 중 치조골 손실과 치근 흡수를 더 보이는 반면 공간폐쇄 후 유지는 더 어렵다고 했다. 또한 발치 후 시간이 오래 경 과되면 치조골의 수직적 높이의 감소가 나타나고 이는 치아의 치관/치근 비율을 변화시켜 이동시 모멘트와 토 크 조절을 더욱 어렵게 한다(Fig. 11). 그리고 협설로 좁 아진 치조돌기의 cortical bone은 교정력에 현저하게 천
Table 4. Case II patient's pre- and post-treatment cephalometric analysis. It shows dental change of both incisors but skeletal pattern was not changed significantly

\begin{tabular}{lrcc}
\hline Measurement & Mean & Initial & Final \\
\hline SNA $\left(^{\circ}\right)$ & 82.5 & $78.6^{*}$ & $78.6^{*}$ \\
SNB $\left(^{\circ}\right)$ & 80.4 & $74.9^{*}$ & $74.9^{*}$ \\
ANB $\left(^{\circ}\right)$ & 2.1 & 3.7 & 3.7 \\
FMA $\left(^{\circ}\right)$ & 22.7 & $34.0^{* *}$ & $33.1^{* *}$ \\
FMIA $\left(^{\circ}\right)$ & 60.7 & 55.6 & 64.7 \\
IMPA $\left(^{\circ}\right)$ & 96.6 & 90.4 & $82.3^{* *}$ \\
L1 to APo (mm) & 4.6 & $9.5^{* *}$ & 5.3 \\
U1 to FH $\left(^{\circ}\right)$ & 116.3 & 120.0 & 118.7 \\
U1 to SN $\left(^{\circ}\right)$ & 108.7 & 106.2 & 104.9 \\
IIA $\left(^{\circ}\right)$ & 124.4 & $115.7 *$ & 126.0 \\
\hline
\end{tabular}

*, 1 standard deviation; **, 2 standard deviation.

$\mathrm{SNA}$, the angle of sella-nasion-A point; $\mathrm{SNB}$, the angle of sellanasion-B point; $A N B$, the angle of A point-nasion-B point; FMA, Frankfort mandibular plane angle; FMIA, Frankfort mandibular incisor angle; IMPA, the angle of the lowermost tangent to the mandible and the long axis of mandibular incisors; L1 to APo, linear distance from tip of lower incisor to A point to pogonion line; $\mathrm{U} 1$ to $\mathrm{FH}$, the angle of the long axis of maxillary central incisors between Frankfort plane; $\mathrm{U} 1$ to $\mathrm{SN}$, the angle of the long axis of maxillary central incisors between sella-nasion plane; IIA, interincisal angle.

천히 반응하게 되어 치료기간을 늘어나게 한다. 이는 늘 어난 치아 이동량과 함께 치근흡수의 위험을 증가시킨 다. 더불어 첫 번째 환자의 초진시 원심경사되어 있던 제 3 대구치는 교정적 힘에 의해 원심경사가 해소되는 방향 으로 치아 이동이 이루어지지만 두 번째 환자의 근심경 사 되어 있던 제 3 대구치는 교정적 힘이 이러한 경향을 더 욱 악화시키므로 tipping 방지와 치근이동을 위한 부가적 인 모멘트의 적용에 상당한 시간이 소요되었고, 그럼에 도 불구하고 적절한 치근 이동을 이루기가 어려웠던 것 으로 생각된다(Fig. 12). 따라서 구치 결손을 보이는 환자 에서 교정적인 치아 이동을 통한 공간 폐쇄 혹은 보철 수 복의 최적화는 환자의 생활치를 최대한 활용하고, 보철 물의 수를 줄일 수 있는 이상적인 치료 방법이지만, 고령 의 환자나 치아 상실 후 오랜 시간이 지나 치조골 흡수가 많이 진행된 경우, 혹은 초진 시 치아가 전방 경사되어 교 정력이 이를 더욱 악화시키는 경우에는 교정치료에 많은 시간이 소모되며 치료 후 안정성을 유지하는 것에도 많 은 노력이 필요하다고 생각된다. 하지만 치조골의 흡수 가 적고, 교정력이 치아를 up-righting 시킬 수 있도록 유 리한 치아 경사를 가지고 있는 경우라면, 교정 치료 기간 

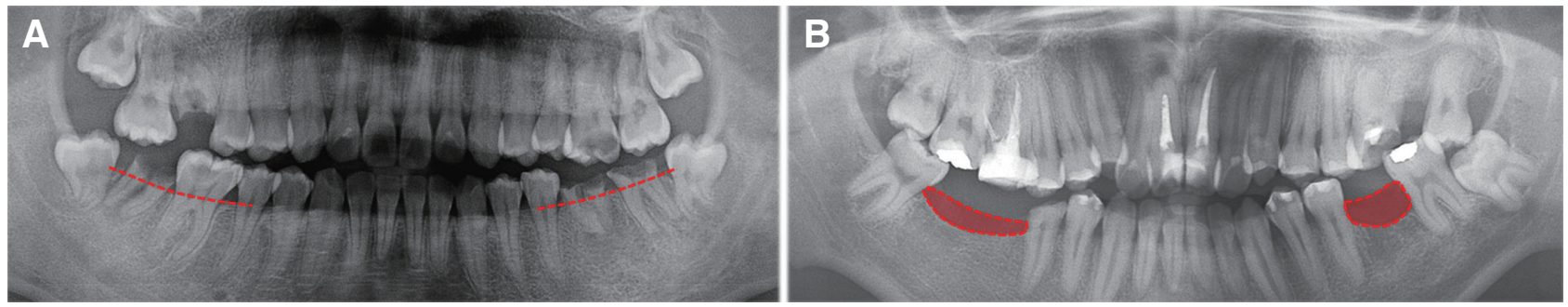

Fig. 11. Comparison of (A) case I and (B) case II patient's pre-treatment alveolar bone level. (A) Redline indicates alveolar bone level of patient I. (B) Red color area indicates absorbed alveolar bone level.
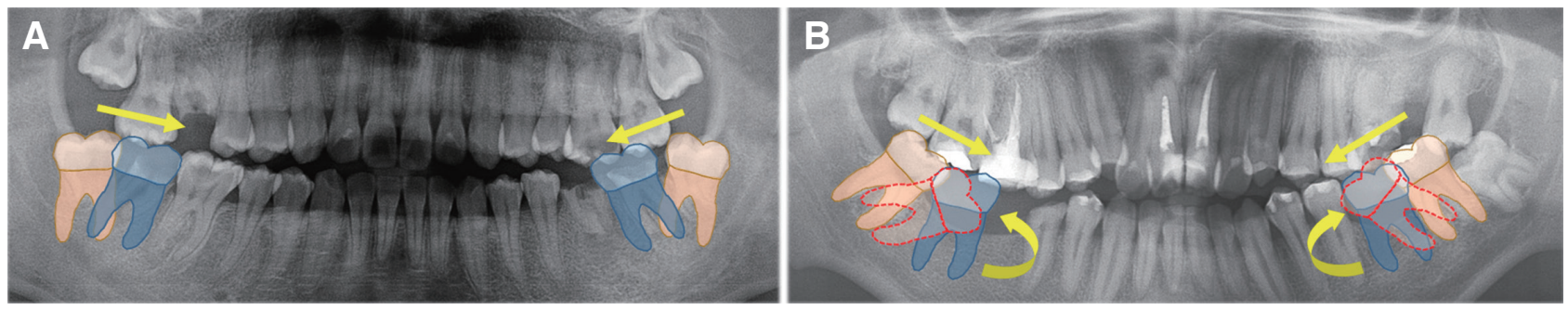

Fig. 12. Protraction force (direction as yellow straight arrow) make distal tipped third molars mesial tipping. (A) Mesial traction force makes leveling easier in patient with distal tipped third molars, (B) but it needs additional time for tipping control as like round yellow arrow in patient with mesial tipped third molars because mesial traction force makes molar more mesial tipping as dotted red teeth.

이 상대적으로 짧고, 어렵지 않게 구치 protraction을 달 성할 수 있으므로, 이를 통해 무치악 부위를 생활치로 대 체하거나 최적의 보철 수복이 가능한 환경을 만들어 줄 수 있으리라 기대된다.

\section{결론}

대부분의 치아 결손부위 후방치아는 근심경사 경향을 보인다. 따라서 공간폐쇄 시, 신중한 tipping control과 치 근의 이동이 적절히 이루어질 수 있는 충분한 유지기간 이 추천된다. 구치부 치아 결손은 기능적, 심리적으로 큰 상실을 초래한다. 따라서 결손부위에 대한 회복이 매우 중요한데, 흔히 인접치, 대합치 등과의 관계에 따른 공간 적 평가와 수정 없이 즉각적인 보철 수복이 이루어지고 있다. 하지만 그 중요성을 생각하여 제 3 대구치의 형태와 위치, 건전성, 맹출 가능성, 환자가 수용 가능한 치료기 간 등을 평가 후 적절한 증례를 선택하여 결손부위를 보 철 수복 없이 자연치로 대체하거나 혹은 최적의 보철 수 복이 가능하게 한다면 보다 효율적이며 궁극적으로 환자 친화적 치료를 시행할 수 있을 것으로 생각된다.

\section{ORCID}

Kang-gyu Lee http://orcid.org/0000-0002-8187-5399

Je-Hyeok Park http://orcid.org/0000-0002-1726-9933

Jin Jeon http://orcid.org/0000-0001-6564-7348

Jae-yoen Kang http://orcid.org/0000-0001-8314-4197

Jong Ghee Kim https://orcid.org/0000-0002-6138-0006

Young-Mi Jeon https://orcid.org/0000-0003-1446-313X

\section{References}

1. Graber LW, Vanarsdall RL, Vig KW, Huang GJ. Orthodontics current principles and technique. 6th ed. Seoul; Elsevier; 2017. p. 644-97.

2. Kokich VG, Spear FM. Guidelines for managing the orthodontic-restorative patient. Semin Orthod 1997;3:3-20.

3. Nanda R. Esthetics and biomechanics in orthodontics. 2nd ed. Seoul; Elsevier; 2015. p. 567-87.

4. Tomonari H, Yagi T, Kuninori T, Ikemori T, Miyawaki S. Replacement of a first molar and 3 second 
molars by the mesial inclination of 4 impacted third molars in an adult with a Class II division 1 malocclusion. Am J Orthod Dentofacial Orthop 2015;147:755-65.

5. Gooris CG, Artun J, Joondeph DR. Eruption of mandibular third molars after second-molar extraction: a radiographic study. Am J Orthod Dentofacial Orthop 1990;98:161-7.

6. Orton-Gibbs S, Crow V, Orton HS. Eruption of third permanent molars after the extraction of second permanent molars. Par1: Assessment of third molar position and size. Am J Orthod Dentofacial Orthop 2001;119:226-38.

7. Orton-Gibbs S, Orton S, Orton H. Eruption of third permanent molars after the extraction of second permanent molars. Part 2: Functional oc- clusion and periodontal status. Am J Orthod Dentofacial Orthop 2001;119:239-44.

8. De-la-Rosa-Gay C, Valmaseda-Castellón E, GayEscoda C. Spontaneous third-molar eruption after second-molar extraction in orthodontic patients. Am J Orthod Dentofacial Orthop 2006;129:33744.

9. De-la-Rosa-Gay C, Valmaseda-Castellón E, GayEscoda C. Predictive model of third molar eruption after second molar extraction. Am J Orthod Dentofacial Orthop 2010;137:346-53.

10. Richardson ME, Richardson A. Lower third molar development subsequent to second molar extraction. Am J Orthod Dentofacial Orthop 1993;104: 566-74. 


\section{구치 결손 환자에서 제3대구치의 교정적 활용}

\section{이강규 ${ }^{1}$, 박제혁 ${ }^{1}$, 전진 $^{1}$, 강재연 ${ }^{1}$, 김정기 ${ }^{1,2}$, 전영미 ${ }^{1,2 *}$}

${ }^{1}$ 전북대학교 치과대학 치과교정학교실 및 구강생체과학연구소

${ }^{2}$ 전북대학교병원 의과학연구소

구치 결손 부위가 장기간 방치될 경우 후방 구치의 근심이동과 대합치 정출 등의 원치 않는 치아이동, 치조골의 소실, 치 아치조 교합의 붕괴를 야기할 수 있다. 따라서 치아상실 후 가능한 빠른 시일 내에 결손 부위에 대한 보철 수복 치료를 권 장하고 있지만, 제 3 대구치 등 잔존 치아를 결손 부위의 적절한 위치로 이동시키는 교정치료를 병행할 경우 최적의 크기 와 형태로 보철 수복이 가능하고, 기능교합 시 힘의 분산을 고르게 할 수 있으며, 수복의 범위를 최소화하여 생역학적으 로 보다 유리한 치주 환경을 조성할 수 있다. 본 증례는 다수의 구치부 치아를 상실한 두 환자를 비교하여 구치부 치아 결손 환자에서 제 3 대구치의 교정적 활용시 고려할 사항에 대해 고찰하고자 한다.

(구강회복응용과학지 2019;35(4):260-9)

주요어: 구치부 치아상실; 구치 결손; 제3대구치 전방견인

*교신저자: 전영미

(54907)전북 전주시 덕진구 건지로 20 전북대학교 치과대학 치과교정학교실, 전북대학교 구강생체과학연구소, 전북대학교병원 의과학연구소 Tel: 063-250-2130 | Fax: 063-250-2139 | E-mail: young@jbnu.ac. kr

접수일: 2019년 10월 11일 | 수정일: 2019년 10월 25일 | 채택일: 2019년 11월 11일 